\title{
Modeling Growth Performance of Juniperus procera (Hochst. Ex. Endl.) Plantations at Boter-Becho Site, Jimma Zone, Southwest Ethiopia
}

\author{
Hailu Belay ${ }^{1 *}$ and Tesfaye Bekele ${ }^{2}$ \\ ${ }^{1}$ Ethiopian Environment and Forest Research Institute, Jimma Center \\ ${ }^{2}$ Ethiopian Environment and Forest Research Institute, Addis Ababa
}

Submission: August 04, 2018; Published: August 14, 2018

*Corresponding author: Hailu Belay, Ethiopian Environment and Forest Research Institute, Jimma Center, Tel: +251-91 177 1514;

Email: hailu.bd@gmail.com

\begin{abstract}
Juniperus procera is the largest Juniper in the world and once occupied the largest mountain forests in Ethiopia. But the forest covers of Juniperus procera were threatened because of various anthropogenic factors. Consequently, the species was included on the IUCN red list of endangered species. Lately, Juniperus procera is becoming part of the plantation establishment program of the state forest department. Studies of the growth performance of Juniperus procera are considered as an important component to design management options for the species. To fill the gap the study was conducted at Boter Becho National forest Priority area, southwest Ethiopia, about 240km from the capital Addis Ababa. It was found that the species has been capable to attain a growth of $13.53 \mathrm{~cm}$ average diameter at breast height and $14.87 \mathrm{~m}$ height at the age of 18years and $26.16 \mathrm{~cm}$ and $21.46 \mathrm{~m}$ mean DBH and height growth respectively at the age of 53years. The mean annual increment of the species at the study site was found to be $6.722 \mathrm{~m} 3 /$ ha. This implied that growth performance the species was promising. The information on growth performance and the growth model of the species is significant in planning forest through establishment of indigenous tree species plantation.
\end{abstract}

Keywords: Growth; Plantations; Diameter; Height; Increment

\section{Introduction}

Juniperus procera is the largest Juniper in the world [1]. In reality the growth of Juniperus procera is considered to be slow. But in favorable conditions it is thought to reach up to $60 \mathrm{~cm}$ diameter and $35 \mathrm{~m}$ height at the age of 100years [2], or else rarely $40 \mathrm{~m}$ tall, with a trunk up to $2 \mathrm{~m}$ diameter [3]. In Ethiopia it was found that plantation of Juniperus procera can attain $37.5 \mathrm{~m}$ height and bole diameter of $107 \mathrm{~cm}$ at the age of 200 -year [4]. According to [5] at similar site it was reported that Juniperus procera can attain mean height of $10 \mathrm{~m}$ and $110 \mathrm{~m} 3 /$ ha volume at the age of about ten years.

With respect to environmental conditions Juniperus procera is well adapted to dry conditions [6]. But according to [5] the species is recommended for semi wet lowlands and wet regions of Ethiopia. This zone is known for long history of sedentary cereal-based mixed agriculture is densely populated [6]. Generally, the species is described as a highland species which prefers cold high ridges and found between of 1000-3500m altitudinal ranges, with an average annual temperature that ranges from $5^{\circ} \mathrm{C}$ to $20^{\circ} \mathrm{C}[2,4]$. Forests which are dominated with Juniperus procera are considered as important component of transitional zone between dry forests, afromontane forest and semi-evergreen forests. Additionally, semi-natural state forest, secondary state forests and church forests remain the most important sources of Juniperus procera in Ethiopia and can contribute in initiation of forest restoration [7]. Besides these natural and semi-natural ranges, the species can also be grown in plantations, in homesteads or on boundaries.

Juniperus procera forests are currently threatened because of multiple anthropogenic factors [1]. The exploitation was intensified in the beginning of 1900 s because of its high quality for saw milling raw material [2]. If there is high destruction and less effort towards establishment of the species is currently included on the IUCN red list of endangered species [8]. However, in the late 1970s J. procera became a part of the plantation establishment program of the state forest department [2]. But the effort to maintain the species was very insignificant. As a result, only few hundred hectares of plantation forests Juniperus procera had been established yet. Boter Becho forest Priority area is one of the sites where the oldest plantation forests of Juniperus procera had been happening. Knowledge on the growth performance of Juniperus procera is important to 
encourage management of plantations forests. Therefore, the aim of this paper is to examine the growth performance of Juniperus procera at Boter Becho Forest Priority area Southwestern parts of the country. Since most of the previous studies carried on Juniperus procera has focused on central and Northern parts of the country.

\section{Materials and Methods}

\section{Description of the Study area}

Boter Becho forest is found in Boter Tolley District, Jimma Zone of Oromia Regional State 240 kilo meters West of Addis Ababa. Its location lies between $8^{0} 12^{\prime \prime}-8^{0} 37^{\prime \prime} \mathrm{N}$ and $37^{0} 06^{\prime \prime}-37^{0}$ 29" E (Figure 1). The forest area borders Limmu Seka district in the west, Nonno district in the north, Chora Boter district in the south and Sekoru districts in the east. The total area of the forest is 35,180 ha which comprises; 1,415 ha plantation and 33,765 ha natural forest out of which 24.3 ha is constituted by Juniperus procera plantations. This area has historically characterized with bimodal rainfall distribution. The short rainy season usually occurs from April to May, whereas the long rainy season lasts from July through October. The mean annual rainfall ranges from $1200-2000 \mathrm{~mm}$. The area has a relatively higher temperature of about $25^{\circ} \mathrm{c}-30^{\circ} \mathrm{c}$ from January to April and having a minimum temperature of $7^{\circ} \mathrm{c}-12^{\circ} \mathrm{c}$ during the month of October to December. Boter Becho forest lies within the altitudinal range of 1500 to $3100 \mathrm{~m}$ above sea level [9]. The Eastern part of the ridge is sharply steep, but more gradual in western side. The hills are divided by numerous valleys. The forest is dominated by high montane forest on slopes and in the valleys up to around $2900 \mathrm{~m}$ above sea level [9].

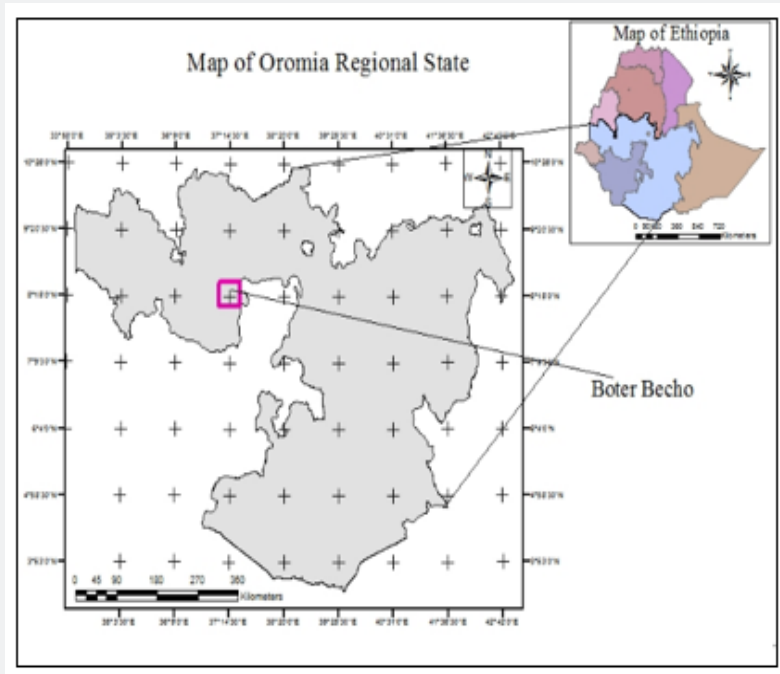

Figure 1: Map showing location of the study area.

\section{Sampling Methodology}

For the purpose of this study circular plots of $5.64 \mathrm{~m}$ radius were systematically laid in the compartment of Juniperus procera plantation forests. Sample plots were determined for each compartment based on homogeneity and heterogeneity of plantation stand. Generally, $4 \%$ sampling intensity for compartments with areas greater than one hectare and five plots for compartments less than a hectare was taken for this study. Locating the plots in the field was done with a GPS and/ or compass to maintain the straightness of plots line and meter for measuring of distance either plot radius or between each plot in both vertically and horizontally. Caliper and Hypsometer were used to measure tree DBH and height. Plot level data was gathered using field form developed for the study. From the data collected individual tree volumes were calculated using tree volume equations developed for the species by [10].

$$
\ln (V)=-2.74112+1.92238 \times \ln (d)+0.90189 \times \ln (h)
$$

Based on the tree volumes computed for each tree were transformed using average plot volumes to obtain per hectare volumes for each age. Similarly, average diameter at breast height was calculated and expressed on per ha basis based on the number tree per hectare per year. Additionally, calculations, mean annual increments in volume at individual tree level and stand (per ha) level were computed.

\section{Results and Discussion}

\section{Description of the Compartments}

Plantations of Juniperus procera plantations were established at Boter Becho site, on seven compartments in the last 53years at various age intervals (Table 1). The compartments comprised un-thinned Juniperus procera plantation forests which were initially planted at spacing of $2 \mathrm{~m}$ by $2 \mathrm{~m}$ wide. The ages of the plantation forests under consideration range from 18years to 53years with the mean age 34years and standard deviation of 15years. This showed that the effort to plant Juniperus procera in the recent years was closed in the last two decades in the study area. For the plantations under consideration, the species was able to attain an average diameter at breast height growth of $13.53 \mathrm{~cm}$ and $14.87 \mathrm{~m}$ height at the age of 18years and $26.16 \mathrm{~cm}$ and $21.46 \mathrm{~m}$ mean DBH and height growth at the age of 53years respectively. The average diameter at breast height (DBH) and total height of the tree species was $20.91 \mathrm{~cm}$ and $17.49 \mathrm{~m}$ respectively. The average basal areas and volume per hectare were $33.47 \mathrm{~m}^{2} /$ ha and $222.851 \mathrm{~m}^{3} /$ ha respectively. Maximum volume production per hectare was attained $\left(335.052 \mathrm{~m}^{3} /\right.$ ha) at the age of 53years. It revealed that as the age increases the volume of the tree also continues to grow. Mean annual increment ranges from 3.526 to $12.731 \mathrm{~m}^{3} /$ ha with the mean $6.722 \mathrm{~m} 3$ and standard deviation of $3.022 \mathrm{~m}^{3}$. The highest mean annual increment was attained at the age of 20years which is $12.731 \mathrm{~m}^{3} /$ ha/year while the mean annual increment at the age of 53years for the oldest stand was about $6.00 \mathrm{~m}^{3} / \mathrm{ha}$ /year. The result showed higher mean annual increment than the study by [11] in Kenya which showed the mean annual increment $(\mathrm{m}+$ / ha/yr) that ranged from $3.73 \mathrm{~m}^{3} / \mathrm{ha} / \mathrm{yr}$ for the same species. 
International Journal of Environmental Sciences \& Natural Resources

Table 1: General description of the compartments.

\begin{tabular}{|c|c|c|c|c|c|c|c|}
\hline Comp. No & Age & DBH & HT & No of Trees/ha & Basal Area /ha & Volume /ha & MAI \\
\hline 1 & 18 & 13.56 & 14.87 & 708 & 10.65 & 72.647 & 4.036 \\
\hline 2 & 20 & 14.97 & 15.90 & 2000 & 37.72 & 254.614 & 12.731 \\
\hline 3 & 27 & 19.17 & 13.89 & 913 & 28.89 & 193.359 & 7.161 \\
\hline 4 & 27 & 22.36 & 12.61 & 344 & 14.98 & 99.857 & 3.698 \\
\hline 5 & 41 & 24.97 & 23.04 & 889 & 46.74 & 308.980 & 7.536 \\
\hline 6 & 53 & 25.21 & 20.66 & 750 & 44.79 & 295.310 & 5.572 \\
\hline 7 & 53 & 26.16 & 21.46 & 900 & 50.51 & 335.052 & 6.322 \\
\hline Mean & 34 & 20.91 & 17.49 & 929 & 33.47 & 222.831 & 6.722 \\
\hline STDEV & 15 & 5.12 & 4.14 & 512 & 15.79 & 103.943 & 3.022 \\
\hline
\end{tabular}

\section{Diameter Vs Height Growth of the Species}

As shown in Figure 2 below height growth and diameter at breast height has logarithmic relationships. Tree algometry patterns (Figure 2) show a typical DBH-height relation: DBH and height initially increase, but later height ceases to increase while DBH continues to increase. The maximum height of Juniperus procera in the study area combined for all compartments of the plantation forests is $26 \mathrm{~m}$ tall at the DBH of $41 \mathrm{~cm}$ while the maximum DBH is $45 \mathrm{~cm}$.

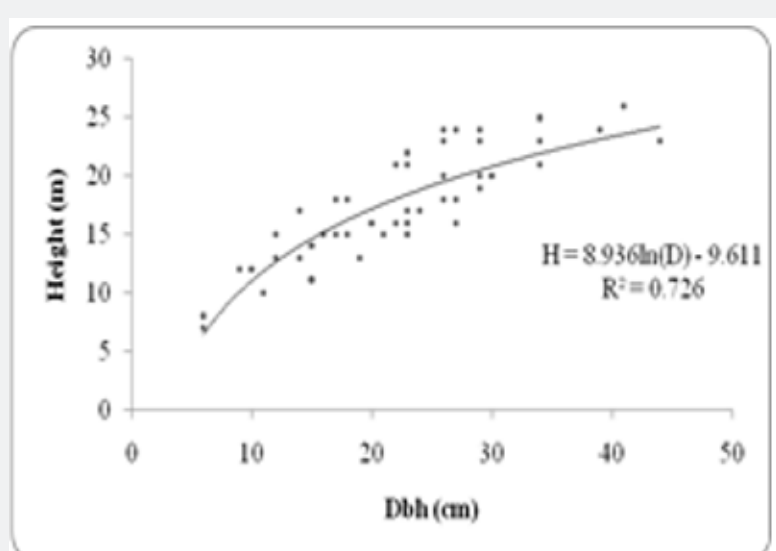

Figure 2: Relationships of Diameter at breast height and height of the trees.

\section{Diameter Class Distribution of the Compartments at Different Ages}

As shown in Figure 3 the frequency distribution of number of trees per hectare out of the seven compartments six are normally distributed. Compartment number six which is 53years old was not normally distributed (roughly looks J-shaped distribution) because some sizes have been illegally cut for construction purpose. In younger compartments showed subsistence of the highest frequencies of individual trees in the $11-15 \mathrm{~cm}$ diameter class. In the middle-aged compartments, the highest frequencies of trees exist in $16-20 \mathrm{~cm}$ diameter class while in older aged compartments the highest numbers of trees occur in $21-25 \mathrm{~cm}$ diameter class.

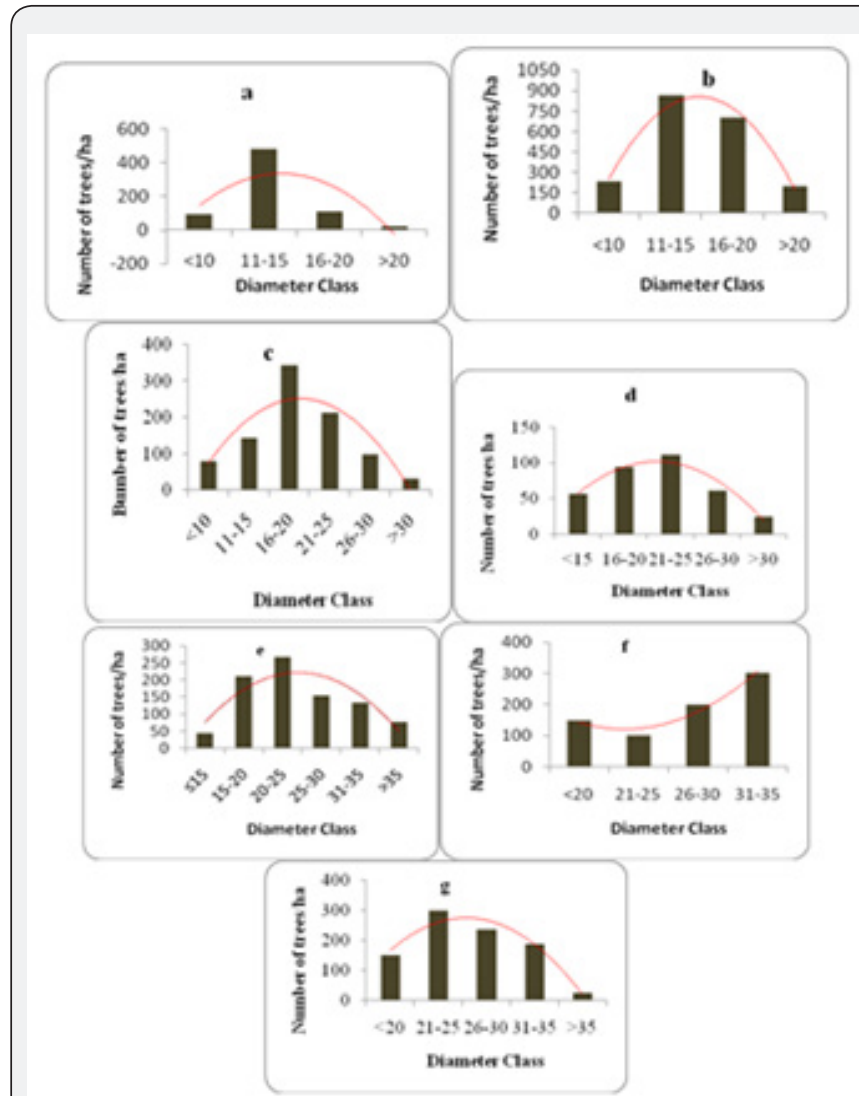

Figure 3: Relationships of Diameter at breast height and height of the trees.

\section{Growth Modeling}

The use of DBH and height to measure growth of trees is usually employed at the individual tree level. In forestry, however, interest is on the growth of the stock as a stand and this is expressed normally by volume $\left(\mathrm{m}^{3}\right)$ per unit area (ha). Volume is elucidated as a function of the DBH and height. Special formulas have been developed for the computation of tree volumes which are normally referred to as volume equations and are developed for the tree species. This equation generally uses a single-entry model and it makes use of DBH in the computations because of 
the obscurity of height measurement in the field. The parameter of the volume model is significant at a probability level of 99 percent and $\mathrm{R}^{2}$ value is 99.4. This is applicable because of the fact that the partial judgment of the reliability of the curves can be made based on the value of $\mathrm{R} 2$ values and the standard errors of the estimates [12]. The use of diameter at breast height alone as independent variable in developing volume model is adequate for the species since it is easier to take the measurement (Figure 4).

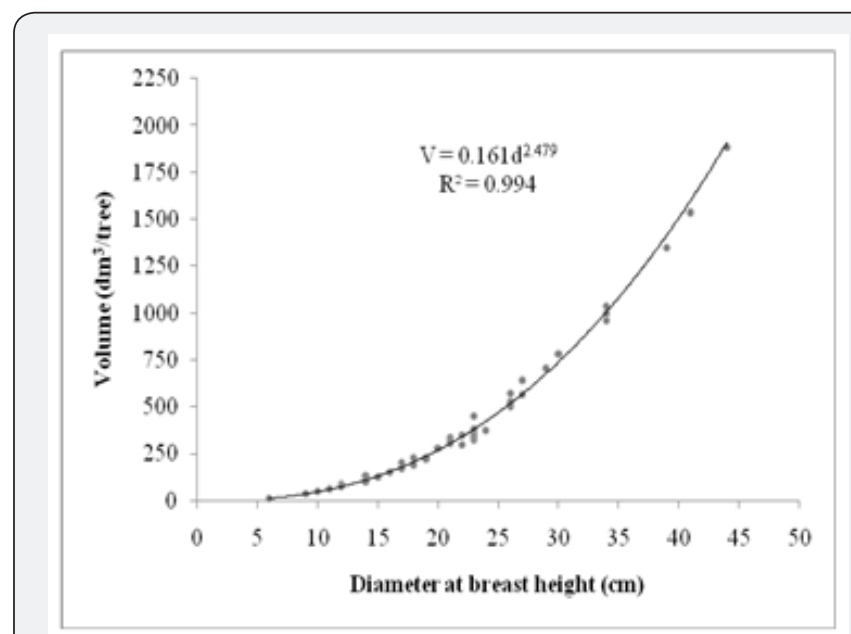

Figure 5: Relationships of diameter at breast height and volume of the tree species.

\section{Conclusion}

Past afforestation and reforestation schemes of the country have targeted mainly the use of exotic species in plantations. To foster this effort indigenous species, require consideration due to growing environmental concerns and awareness. Juniperus procera is one of the most important indigenous species which have social, environmental and economical values. However, growth and yield potential of the species was not well developed to inform decision makers and enterprises in the forest sector. The information is critical in planning natural forest restoration and forestry initiatives that is expected to contribute to restoring the forest to its ecological functioning.

\section{References}

1. L Negash, B Kagnew (2013) Mechanisms for the successful biological restoration of the threatened African pencilcedar (Juniperus procera Hochst. ex. Endl., Cupressaceae) in a degraded landscape. Forest Ecology and Management 310: 476-482.

2. V Pohjonen, T Pukkala (1992) Juniperus procera Hocht. Ex. Endl. In Ethiopian Forestry. Forest Ecology and Management 49(1-2): 75-85.

3. E Worku, T Soromessa (2015) Allometric Equation for Biomass Determination in Juniperus procera Endl. and Podocarpus falcatus Mirb of Wof-Washa Forest: Implication for Climate Change Mitigation. American Journal of Life Sciences 3(3): 190-202.

4. C Couralet, H Bakamwesiga (2007) Juniperus procera Hochst. ex Endl. In: Louppe D, Oteng-Amoako AA, Brink M, (Eds.); PROTA (Plant Resources of Tropical Africa / Ressources vegetales de l Afrique tropicale), Wageningen, Netherlands.

5. Orlander G (1986) Growth of some forest trees in Ethiopia and suggestions for species selection in different climatic zones. Swedish University of Agricultural Science Department of Silviculture, Umea Sweden p. 61.

6. Leipzig (1996) Ethiopia: Country report to the FAO International Technical conference on plant genetic resources. Addis Ababa, Ethiopia p. 51.

7. Sterck FJ, Couralet C, Nangendo G, Wassie Al, Sahle Y, et al. (2010) Juniperus procera (Cupressaceae) in Afromontane Forests in Ethiopia: From Tree Growth and Population Dynamics to Sustainable Forest Use. ES_DFEA 30(4): 291-303.

8. Mahari A, Abera S, Alebachew A (2015) Growth Response of Juniperus Procera (Hochst. Ex Endl.) on Calcaric Cambisol and Eutric Regosol in the Dry lands of Northern Ethiopia. International Journal of Plant, Animal and Environmental Sciences 3(4): 97-101.

9. T Seta, S Demissew, Z Woldu (2018) Litterfall dynamics in Boter-Becho Forest: Moist evergreen montane forest of Southwestern Ethiopia. Journal of Ecology and the Natural Environment 10(1): 13-21.

10. VM Pohjonen (1991) Volume equations and volume tables of Juniperus procera Hocht. ex. Endl. For Ecol. Manage 44(2-4): 185-200.

11. JK Cheboiwo, MR Ochieng, J Mbinga, F Mutiso (2015) Potential Growth, Yields and Socioeconomic Benefits of Four Indigenous Species for Restoration in Moist Forests, Mau Kenya. Journal of Environment and Earth Science 5(6): 72-84.

12. Cochran PH (1979) Site index and height growth curves for managed, even-aged stands of Douglas-fir east of the Cascades in Oregon and Washington. USDA For Servo Res Pap p. 16.

\section{Your next submission with Juniper Publishers} will reach you the below assets

- Quality Editorial service

- Swift Peer Review

- Reprints availability

- E-prints Service

- Manuscript Podcast for convenient understanding

- Global attainment for your research

- Manuscript accessibility in different formats ( Pdf, E-pub, Full Text, Audio)

- Unceasing customer service

Track the below URL for one-step submission https://juniperpublishers.com/online-submission.php 